Mieczysław PIGŁAS, Tomasz RADOŃ, Marek SZYMAŃSKI, Antonina KRUTKOW, Alicja PRZYSTAWSKA

Air Force Institute of Technology (Instytut Techniczny Wojsk Lotniczych)

\author{
SYSTEM INFORMATYCZNEGO WSPARCIA \\ EKSPLOATACJI WOJSKOWYCH STATKÓW \\ POWIETRZNYCH SI SAMANTA JAKO NARZĘDZIE \\ WSPOMAGAJĄCE ZARZĄDZANIE ZASOBAMI \\ LOGISTYCZNYMI
}

\title{
Information system support for military aircraft operations SI SAMANTA as a tool to support logistic resource management
}

\begin{abstract}
Streszczenie: Przedstawiono istotę stosowania i funkcjonowania informatycznych systemów wspomagania zarządzania realizacja procesów złożonych na przykładzie SI SAMANTA. Skupiono się na wspomaganych obszarach i funkcjach systemu. Określono jego role $w$ procesie eksploatacji sp oraz wptyw na bezpieczeństwo latania. Scharakteryzowano możliwości informatycznego przetwarzania gromadzonych $w$ bazie danych oraz informacji, podano możliwości analitycznego wykorzystania ich przez użytkownika np. do oceny niezawodności statków powietrznych, skuteczności napraw samolotów i śmigłowców. Przedstawiono kierunki, które specjaliści z ITWL zamierzaja rozwijać w celu zwiększenia użyteczności prezentowanego systemu.
\end{abstract}

Słowa kluczowe: systemy informatyczne, informatyczne wsparcie, eksploatacja, statki powietrzne, samoloty i śmigłowce, SI SAMANTA

\begin{abstract}
The article addresses the functioning of IT support systems for the implementation of complex processes based on the SI SAMANTA. The paper focused on the supported areas and functions of the IT system. The role of this system in the a/c operation process and its impact on flying safety were determined. The possibilities of IT processing of data and information were characterized, along with their analytical use, e.g. for the assessment of aircraft reliability and maintenance efficiency of the repairs of airplanes and helicopters. The directions that are intended to be developed to increase the usability of the presented system were also discussed.
\end{abstract}

Keywords: IT systems, IT support, operation, aircraft, planes and helicopters, SI SAMANTA 


\section{Wstęp}

Podstawową funkcją Systemu Logistycznego Sił Zbrojnych RP, wynikającą z zapisów dokumentów doktrynalnych, jest zapewnienie bezpieczeństwa państwa m.in. poprzez wykonywanie działań związanych z przynależności do Sojuszu Północnoatlantyckiego. Ponadto istnieją jeszcze inne obszary, w które angażowane są Siły Zbrojne RP np. sytuacje kryzysowe na terenie kraju [18]. W powyższych działaniach lotnictwo wojskowe realizuje swój udział poprzez zachowanie odpowiedniego poziomu gotowości do realizacji operacyjnych zadań lotniczych. Poprzedzają je szkolenia lotnicze prowadzone w celu doskonalenia umiejętności personelu latającego w procesie eksploatacji statków powietrznych (sp), przy wysokim zaangażowaniu personelu służby inżynieryjno-lotniczej (SIL).

Eksploatacja jako jeden z etapów cyklu życia wojskowych statków powietrznych jest jednym z najważniejszych okresów, ponieważ właśnie wtedy są one użytkowane zgodnie ze swoim przeznaczeniem. Całokształt aspektów dotyczących wielu zagadnień, które obejmuje proces eksploatacji sp, powoduje, że obok fazy konstruowania i wytwarzania staje się on bardzo kosztownym etapem w okresie ich istnienia [15]. Dotyczy to statków powietrznych, będących od dawna na wyposażeniu Sił Zbrojnych oraz tych, które zostały ostatnio wprowadzone do eksploatacji. Niezależnie jednak od wieku samolotów i śmigłowców, użytkowanie ich wymaga obecnie użycia wielu sił i środków zapewniających, że eksploatacja będzie realizowana $\mathrm{z}$ zachowaniem odpowiedniego poziomu bezpieczeństwa. Wymagają tego zarówno nowoczesne tj. technologicznie zaawansowane statki powietrzne np. F-16 i M346, jak również samoloty i śmigłowce należąc do tzw. starzejącej się techniki lotniczej, do której zaliczamy np. Su-22 czy Mi-14. Bezpieczeństwo, o którym mowa kształtowane jest poprzez utrzymywanie zdatności do lotu całej floty statków powietrznych SZ RP. Wszystko to ma na celu, uniknięcie niebezpiecznych i kosztownych skutków zdarzeń lotniczych.

W związku z tymi wyzwaniami wykonanie wszystkich procesów cząstkowych eksploatacji, prowadzonych w oparciu o obowiązujące przepisy, powinna być skuteczna i efektywna. Ważne jest przy tym zachowanie odpowiednio wysokiej jakości, która jest gwarantem powodzenia realizacji procesu eksploatacji sp. W celu sprostania opisanym wyżej oczekiwaniom i przeciwdziałania zagrożeniom funkcjonowania lotniczych systemów eksploatacyjnych wprowadza się różnego rodzaju narzędzia informatycznego wsparcia. To one dzięki swoim zaletom powodują, że zarządzanie procesem eksploatacji sp staje się łatwiejsze i bardziej efektywne.

\section{Informatyczne wsparcie procesu eksploatacji sp - wprowadzenie}

Proces eksploatacji wojskowych statków powietrznych prowadzony jest w Systemie Logistycznym Sił Zbrojnych Rzeczypospolitej Polskiej (SL SZ RP), natomiast bezpośrednio za wszystkie przedsięwzięcia, związane z obszarami eksploatacji sp odpowiedzialny 
jest Podsystem Techniczny. Struktura Systemu Logistycznego SZ RP, który według klasyfikacji instytucjonalnej logistyki należy do obszaru mikrologistyki, przedstawiono na rys. 1. Pojęcie eksploatacji zawiera w sobie szeroki zasób znaczeń, należy więc przyjrzeć się im dokładniej. Podstawowa definicja to: zespół celowych działań organizacyjno-technicznych i ekonomicznych ludzi ze sprzętem wojskowym ( $\mathrm{SpW}$ ) oraz relacje między nimi, od chwili wprowadzenia SpW do SZ RP, aż do jego wycofania [12]. Jednocześnie należy zauważyć, że pojęcie eksploatacja statków powietrznych bardzo często określane jest procesem eksploatacji sp. Oznacza on wówczas zmianę następujących po sobie w sposób uporządkowany stanów w cyklu eksploatacyjnym. W rzeczywistości oznacza to, że eksploatacja statków powietrznych definiowana jako proces obejmuje złożony łańcuch związanych ze sobą procesów cząstkowych, w których dochodzi do oddziaływania wzajemnego pomiędzy obiektem eksploatacji, czyli statkiem powietrznym a człowiekiem i otoczeniem na ziemi lub w locie [16].

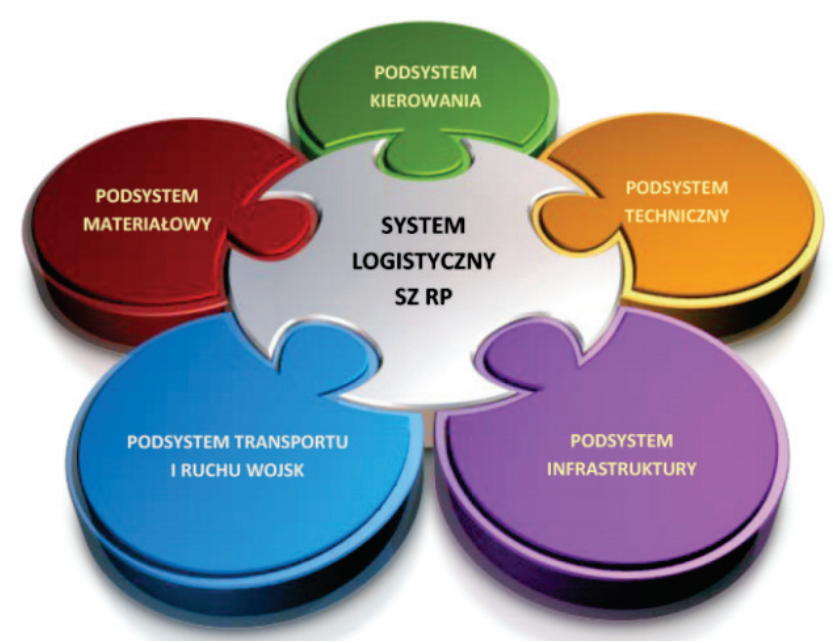

Rys. 1. Struktura Systemu Logistycznego SZ RP [18]

Należy tu również uwzględnić procesy zachodzące w samym obiekcie eksploatacji, którym może być samolot lub śmigłowiec. Ulegają one bowiem oddziaływaniu przez czynniki, które charakteryzują otoczenie i mają bezpośredni wpływ na ich trwałość. Przez otoczenie rozumie się oddziaływanie czynników klimatyczo-przyrodniczych [9]. Eksploatację można również rozpatrywać w ujęciu systemowym, tworzy ona wówczas system eksploatacji, który umiejscowiony jest w strukturze jednostki lotniczej obok innych elementów bezpośrednio wspierających proces eksploatacji. Należą do nich m.in.: zabezpieczenie logistyczno-techniczne (ZLT), naziemna obsługa sp (NOsp), służby ubezpieczenie lotów (SUL), służby ruchu lotniczego (SRL). Elementami systemu są również: personel latający (PL), personel służby inżynieryjno-lotniczej (PSIL), personel kierowania lotami (PKL) oraz systemy informatycznego wsparcia eksploatacji (SIWE) (rys. 2) [7,16]. 


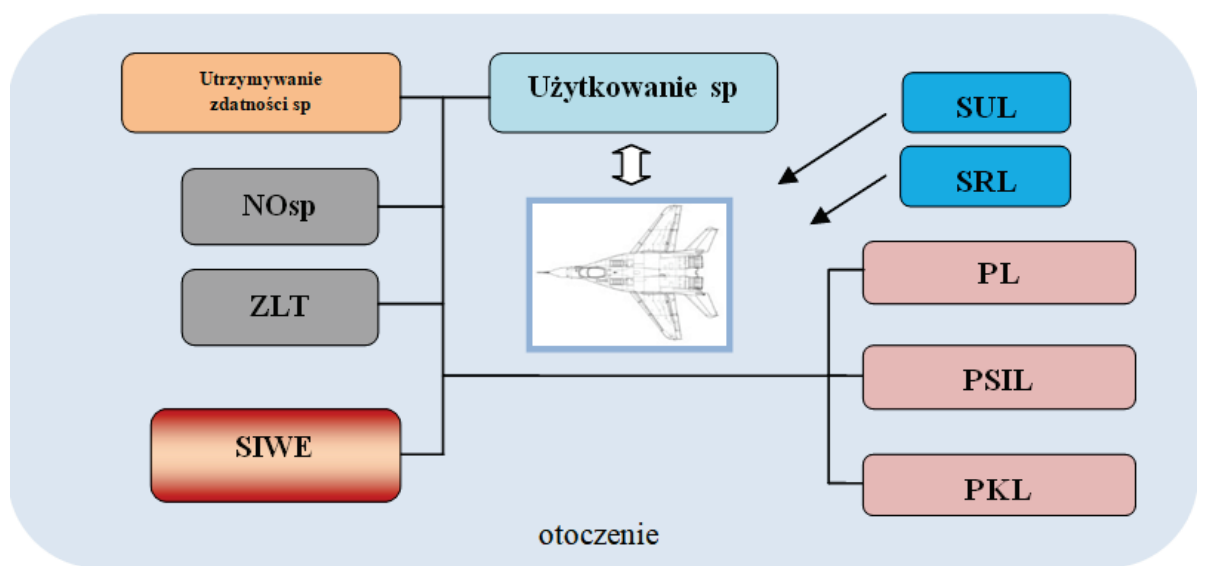

Rys. 2. Ogólne zobrazowanie elementów systemu eksploatacji sp

W eksploatacji można wskazać dwa obszary jej działania: użytkowanie sp oraz utrzymywanie zdatności sp. Wyróżnić jeszcze można jeden obszar tzw. badania eksploatacyjne, które uzupełniają eksploatację. Obejmują one czynności, mające na celu zapewnienie m.in. właściwej niezawodności sp, bezpieczeństwa lotów, a także efektywności systemu eksploatacyjnego. Podsumowując eksploatacja to szeroko rozumiane pojęcie, jednak mówiąc o użytkowaniu sp mamy na myśli proces eksploatacji, w którym samolot lub śmigłowiec powinien być gotowy do przeprowadzenia zadania lotniczego. Jest to możliwe pod warunkiem utrzymywania sp w stanie zdatności technicznej (funkcjonalnej) [14], co jest osiągane dzięki realizacji wymaganych procesów złożonych eksploatacji i obejmuje m.in.:

- obsługiwanie (przeglądy okresowe, kontrole stanu technicznego, czynności profilaktyczne),

- naprawę (to zespół przedsięwzięć organizacyjnych i technicznych mających na celu przywrócenie sprzętu lotniczego do stanu zdatności technicznej),

- bieżące zaopatrywanie np.: w paliwo, tlen itp.,

- realizacje wymagań zawartych w aktualnej dokumentacji technicznej oraz innych dokumentach normatywnych takich jak: biuletyny, listy serwisowe, profilaktyki i dyrektywy zdatności.

Należy równocześnie pamiętać, że z uwagi na ogólny rozwój technologiczny, możliwą poprawę właściwości sp oraz powstające nowe zagrożenia w procesie eksploatacji sp nie jest on procesem zamkniętym. W rzeczywistości oznacza to, że zasady eksploatacji podlegają ciągłym udoskonaleniom. Wykonuje się to m.in. poprzez modernizację obiektów eksploatacji, czyli statków powietrznych [17], zwiększanie ich norm eksploatacji [15], zmianę strategii eksploatacji [8] czy ulepszanie struktur funkcjonalnych systemu eksploatacji np. poprzez zwiększenie użyteczności systemów informatycznego wsparcia. 
Nadzór nad prawidłową eksploatacją lotnictwa SZ prowadzi Minister Obrony Narodowej, a jego organem wykonawczym jest Szef Szefostwa Techniki Lotniczej Inspektoratu Wsparcia Sił Zbrojnych (IWspSZ) - Główny Inżynier Wojsk Lotniczych (GIWL) [4]. Jednym z głównych zadań GIWL jest zarządzanie informatycznym wsparciem eksploatacji sp. W lotnictwie wojskowym SZ RP informatyczne wspomaganie prowadzone jest poprzez stosowanie Systemu Informatycznego Wsparcia Eksploatacji statków powietrznych (SIWEsp), o nazwie SI SAMANTA. System ten został zakwalifikowany do tzw. narodowych systemów informatycznych wspierających kierowanie logistyką i zarządzanie zasobami logistycznymi, obok innych systemów takich jak: ZWIS-RON, SI KONWÓJ, SI CEP-S [21].

Twórcą przedmiotowego systemu SI SAMANTA jest Instytut Techniczny Wojsk Lotniczych (ITWL). To właśnie Instytut w latach osiemdziesiątych zaprojektował i opracował pierwszą wersję systemu, która pod nazwą SKANSEN zapewniała gromadzenie danych eksploatacyjnych statków powietrznych, w tym m.in. informacji o niesprawnościach sp i ich uszkodzeniach. Źródłem tych danych były papierowe druki kart niesprawności, zawierające dane o uszkodzonych elementach, kodowane według katalogów dekompozycji statków powietrznych. Kolejnym systemem opracowanym przez ITWL był system informujący o stanie i rotacji silników lotniczych o nazwie NEFRYT. Innym systemem, który pojawił się do wspierania eksploatacji sp, był system SAN, umożliwiający automatyczną obróbkę danych, który znacząco poprawił możliwości kompleksowej analizy i oceny procesu eksploatacji sp m.in. w zakresie niezawodności sp i bezpieczeństwa latania.

Duży skok w rozwoju systemów IT stosowanych w lotnictwie wojskowym nastąpił pod koniec lat dziewięćdziesiątych, kiedy nastąpił gwałtowny rozwój informatyzacji. Wówczas powstała pierwsza wersja systemu SAMANTA. Była ona opracowana w środowisku Pascal i zastąpiła system NEFRYT oraz SAN. Dalszy rozwój systemu SAMANTA umożliwiło wykorzystanie sieci internetowej, dzięki czemu dane mogły być przesyłane do centralnej bazy danych, co znacznie zwiększyło efektywność działania systemu. Stworzony wówczas system SAMANTA.BIS opracowano, używając zaawansowanego narzędzia informatycznego firmy Oracle, jakim był Power Object. Z uwagi jednak na to, że była to aplikacja desktopowa, dane przez nią gromadzone były szyfrowane i synchronizowane z bazą w ITWL okresowo. Sytuacja taka trwała do momentu pojawienia się w jednostkach teleinformatycznej sieci MILNET. W celu wykorzystania pełnych możliwości nowej infrastruktury sieciowej w zakresie transmisji danych zespół specjalistów z ITWL opracował SI SAMANTA, która działa online. System jest aplikacją webową (www), co znacząco spowodowało jakościowy skok w funkcjonowaniu informatycznego wsparcia eksploatacji sp. Wdrożony sześć lat temu system, działa obecnie z powodzeniem, a jego najważniejszą funkcją jest możliwość przesyłania danych i generowania informacji przez użytkownika bez opóźnień, tj. w czasie rzeczywistym. System opracowano z wykorzystaniem oprogramowania PHP, Oracle i Apache. 


\section{Istota stosowania informatycznego wsparcia $w$ procesie eksploatacji sp}

Jak wynika z wcześniejszych rozważań, proces eksploatacji sp nie jest prostym przedsięwzięciem, jednak świadome wprowadzanie do struktur funkcjonalnych jednostek lotniczych narzędzi informatycznych w istotny sposób ułatwia jego realizację. Wdrażanie systemów informatycznego wspomagania zarządzaniem zasobami: ludźmi, obiektami, procesami czy gospodarką materiałową, jest jednym z kroków do polepszenia efektywności prowadzenia działalności instytucji. Należy jednak pamiętać, że główną rolą systemów jest wspieranie kadry zarządzającej ww. obszarami, a nie ich zastępowanie [3]. Używanie systemów informatycznych stało się w dzisiejszych czasach nieuniknione, a pomocą ich implementowania są odpowiednie dokumenty formalne. Podstawowym dokumentem nakładającym obowiązek stosowania systemu informatycznego w eksploatacji wojskowych sp jest dokument doktrynalny „Wsparcie i zabezpieczenie techniczne Sił Zbrojnych Rzeczypospolitej Polskiej, Zasady funkcjonowania" [22] wprowadzony do użytku w 2017 r. O SIWEsp jest również mowa w „Instrukcji o gospodarowaniu mieniem techniki lotniczej” [4]. Kolejnym dokumentem jest „Instrukcja służby inżynieryjno-lotniczej lotnictwa Sił Zbrojnych Rzeczypospolitej Polskiej (ISIL-2017)” [6], która zawiera zasadnicze informacje o zadaniach i zakresie stosowania SIWEsp w realizacji procesu eksploatacji sp, określone w formie wymagań.

SI SAMANTA jest systemem wieloszczeblowym, przeznaczonym głównie do stosowania w strukturze służby inżynieryjno-lotniczej jednostek lotniczych SZ RP. Swoim szerokim spektrum oddziaływania zapewnia wsparcie praktycznie wszystkim statkom powietrznym eksploatowanym w SZ RP, co świadczy, że jest unikatowy. Ogólną strukturę SIWEsp prezentuje rys. 3 .

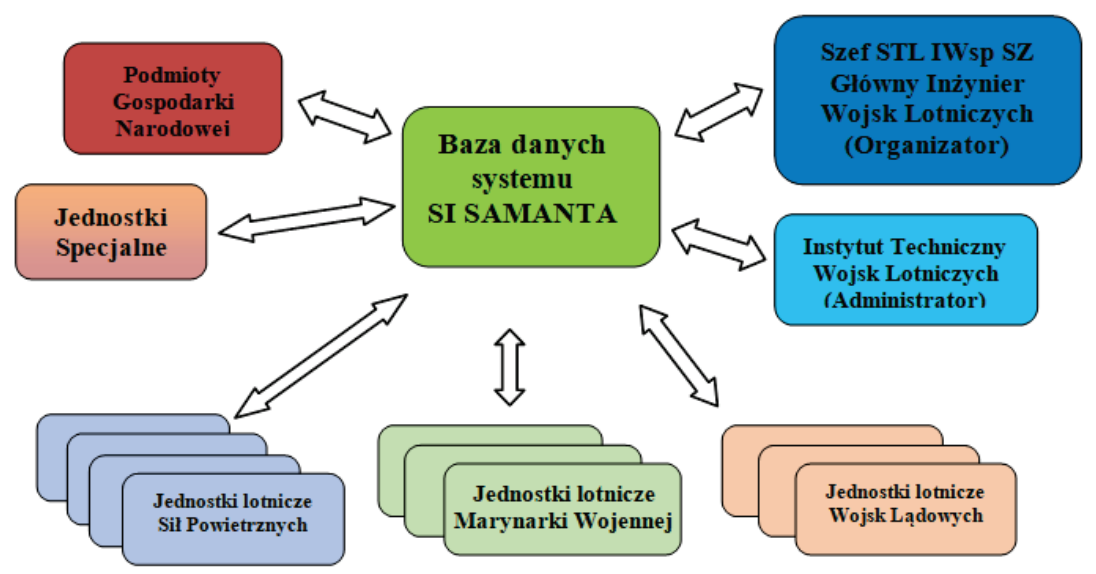

Rys. 3. Ogólna struktura systemu informatycznego wsparcia eksploatacji sp 
Organizatorem SIWEsp jest Szefostwo Techniki Lotniczej IWsp SZ. Ważną rolę w procesie użytkowania SI SAMANTA pełni również Administrator, którym jest ITWL. To Instytut jako twórca systemu bierze aktywny udział w eksploatowaniu systemu przez użytkowników, zapewniając m.in. asystę techniczno-informatyczną. Odgrywa również ważną rolę, poprze aktualizacje systemowe oraz partycypację w określaniu kierunków rozwoju funkcjonalnych właściwości systemu.

SI SAMANTA umożliwia gromadzenie danych i informacji eksploatacyjnych, przechowywanie i prezentowanie w postaci specjalistycznych raportów lub zestawień specjalistom. System pełni również ważną rolę w szeroko rozumianym wspomaganiu procesów informacyjno-decyzyjnych różnych służb. Dzięki temu jest źródłem wiedzy wykorzystywanej przez służby operacyjne, dostarczając informacje o stanie samolotów i śmigłowców tzn. czy są gotowe do użycia. Służba inżynieryjno-lotnicza natomiast pozyskuje informacje i buduje wiedzę niezbędną do kierowania i sterowania realizacją procesów eksploatacyjnych sp na poziomie strategicznym (np. planowania rocznego wykorzystania resursów sp) oraz operacyjnym (np. realizacji obsługiwania). Wszystkie te procesy najczęściej realizuje się w cyklu PDCA (planuj>wykonaj>sprawdź>działaj), preferowanym przez normę ISO 9000:2015. Do innych ważnych zalet stosowania systemów informatycznego wsparcia należą: jednokrotne wprowadzanie danych, szybki i łatwy dostęp do danych, bezpieczeństwo danych (dostęp dla upoważnionych użytkowników), automatyzacja oraz powtarzalność procesów, minimalizacja popełnianych błędów oraz zmniejszenie ryzyka niezrealizowania procesów.

Jednocześnie posiadanie świadomości eksploatacyjnej o różnych strategiach, według których użytkuje się statki powietrzne, należące do floty SZ RP, pozwoliło na zaprojektowanie systemu w taki sposób, aby spełniał on wymagania również w tym zakresie. Do podstawowych strategii eksploatacji sp należą:

- według zasobu pracy sp (według resursu), którym może być resurs techniczny lub resurs międzynaprawczy,

- według stanu technicznego, oparta na ocenie bieżącego stanu technicznego sp poprzez kontrolę parametrów.

W rzeczywistości występuje tendencja do przechodzenia od eksploatacji według resursu do eksploatacji według stanu technicznego. Dzięki temu możliwe jest uzyskanie wyższej efektywności wykorzystania sp, tj. korzystniejszego rachunku kosztów eksploatacji [8]. SIWEsp należy ponadto do grupy tzw. systemów proaktywnych, które mogą wspomagać zarządzanie bezpieczeństwem lotów, poprzez realizację analiz zdarzeń lotniczych zaistniałych z przyczyn technicznych [11]. Dzięki temu informacje przetwarzane w systemie mogą być wykorzystywane do podejmowania przedsięwzięć, takich jak: identyfikacja zagrożeń, analiza ryzyka oraz przeciwdziałanie poprzez wprowadzanie działań profilaktycznych i korygujących.

SI SAMANTA jest systemem dedykowanym, ponieważ realizowany jest według zasady tworzenia funkcjonalności systemu specjalnie pod konkretne wymagania, tj. zarządzanie określonymi zasobami i procesami. W obszarze eksploatacji sp głównymi zasobami są: statki powietrzne i ich wyposażenie, sprzęt do naziemnej obsługi sp, części zapasowe 
i eksploatacyjne, dokumentacja oraz personel SIL. Oznacza to, że w rzeczywistości system łączy wybrane funkcje systemów klasy m.in. ERP (Enterprise Resource Planning), WMS (Warehouse Management System), HRM (Human Resource Management) i EDI (Elektronic Data Interchange). Połączenie tych funkcji relacjami powoduje, że system jest bardziej użyteczny i efektywny niż w przypadku, gdyby poszczególne części działały oddzielnie.

\section{Obszary i funkcje informatycznego wspomagania procesów eksploatacji sp}

Użyteczność systemów informatycznego wspomagania mierzy się obszarami, które je obejmują i funkcjami, realizowanych w nich. Podobnie jest w przypadku systemu informatycznego SI SAMANTA, którego zakres funkcjonalny jest bardzo szeroki. Poniżej zaprezentowano podstawową charakterystykę użyteczności.

Najważniejszą funkcją jest możliwość wprowadzania do systemu oraz gromadzenia danych ilościowo-jakościowych związanych z eksploatacją obiektów administrowanych w systemie, tj. samolotów, śmigłowców ich zespołów i wyposażenia (rys. 4). Należą do nich np.:

- dane identyfikacyjne np. typ, wersja, nr fabryczny, data produkcji,

- dane ewidencyjne statków powietrznych związane z ich rotacją np. przyjęcie do eksploatacji, przybycie lub ubycie z jednostki i zdjęcie ze stanu (kasacja), co umożliwia śledzenie obiektu w jego cyklu życia,

- dane eksploatacyjne statku powietrznego charakteryzujące m.in. ich trwałość (czas pracy na ziemi, czas lotu, ilość lądowań itp.).

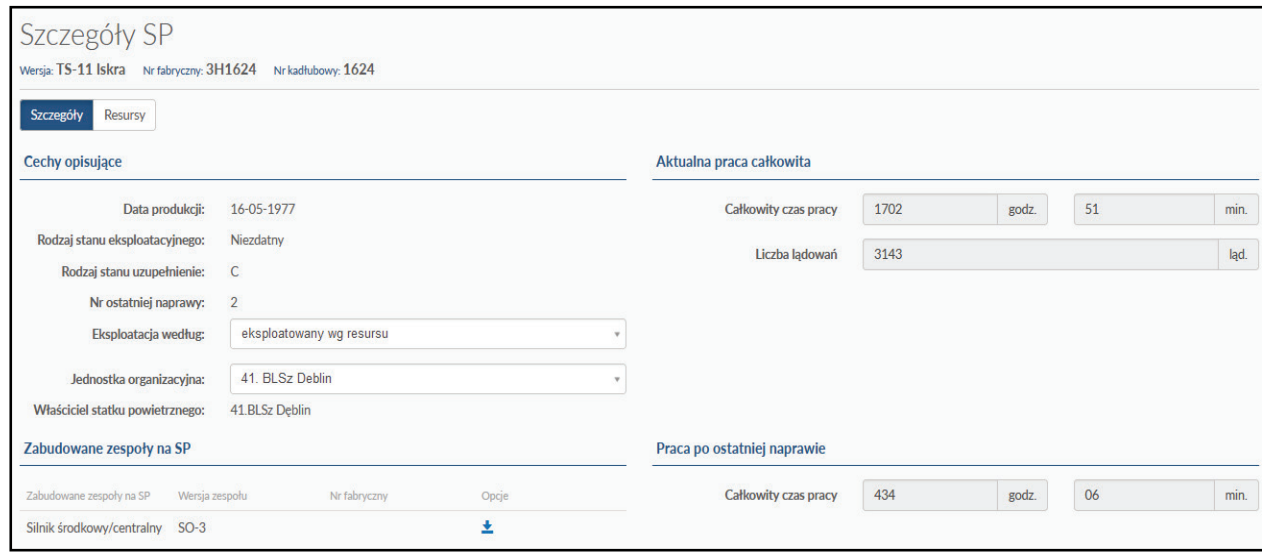

Rys. 4. Przykładowe dane ewidencyjno-eksploatacyjne sp (archiwum ITWL) 
Za przebieg procesu eksploatacji sp w jednostce lotniczej odpowiada przede wszystkim kierownictwo służby inżynieryjno-lotniczej, którymi są wysoko wykwalifikowani inżynierowie. Najważniejsze zadania realizowane przez ww. sprowadzają się do zarządzania eksploatacją techniki lotniczej, w tym posiadaną flotą statków powietrznych, w taki sposób, aby zapewnić ich dostępność do prowadzenia zadań lotniczych. Osiąga się to poprzez skrupulatne i rzetelne planowanie niezbędnych czynności w procesie eksploatacji w celu utrzymania zdatności technicznej sp. Ostateczny efekt planowania utrwalany jest w SIWEsp w postaci cyfrowych planów eksploatacji. Stworzony w ten sposób plan eksploatacji (rys. 5) zastąpił prowadzoną wcześniej wersję papierową, a zaletą jego jest łatwa aktualizacja. Dzięki informatyzacji planu eksploatacji można analizować skuteczność planowania np. zużycia resursu sp (rys. 6).

\begin{tabular}{|c|c|c|c|c|c|c|c|c|c|c|c|c|}
\hline \multicolumn{13}{|c|}{ Th Is-11 Iskra, nr kad lubowy 1901, nr fabryczuy 3H1901 } \\
\hline & & Styczen & Luty & Marzec & Kwiecien & Maj & Czerwiec & Lipiec & Sierpień & Wrzesien & Październik & \\
\hline & & I III III IV & I II III IV & I III III IN & I III III IV & I III III IV & I III III IV & I III III IV & I III III N & I III III $\mathrm{N}$ & I III III IV & \\
\hline \multicolumn{2}{|c|}{ Plan zużycia resursu } & 0 & 0 & 2 & 6 & 2 & 6 & 5 & 6 & 8 & 7 & \\
\hline \multicolumn{2}{|c|}{ Zrealizowany resurs } & 0 & 0 & 0 & 1 & 12 & 15 & 1 & 0 & 6 & 5 & \\
\hline \multicolumn{2}{|c|}{$\begin{array}{l}\text { Pozostałość resursu } \\
\text { technicznego }\end{array}$} & 1785 & 1785 & 1785 & 1784 & 1772 & 1758 & 1757 & 1757 & 1751 & 1746 & \\
\hline \multicolumn{2}{|c|}{$\begin{array}{l}\text { Pozostałość resursu } \\
\text { międzynaprawczego }\end{array}$} & 293 & 293 & 293 & 292 & 280 & 266 & 265 & 265 & 259 & 254 & \\
\hline Narawo & Plan & & & & & & & & & & & \\
\hline Naprawy & Realizacja & & & & & & & & & & & \\
\hline Obsturi & Plan & & & & & & & & & & & \\
\hline Obsługi & Realizacja & & & & & & & & & & & \\
\hline Rivetyon & Plan & & & & & & & &. & & & \\
\hline Buletyny & Realizacja & & & & & & & & & & & \\
\hline & Plan & & & & & & & & & & & \\
\hline Wybudowy & Realizacja & & & & & & & & & & & \\
\hline
\end{tabular}

Rys. 5. Przykładowy plan eksploatacji sp (archiwum ITWL)

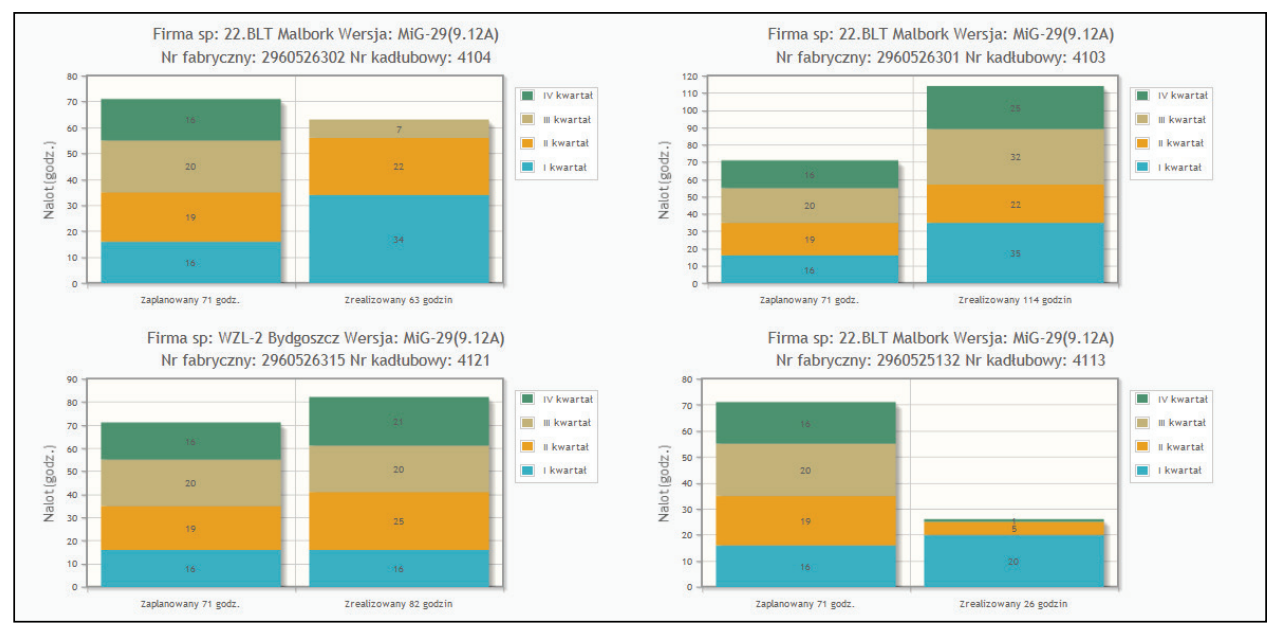

Rys. 6. Przykładowa realizacja wykorzystania resursu sp (archiwum ITWL) 
System posiada również funkcję ustawiania dziennych stanów eksploatacyjnych (rys. 7), w celu określania stanu zdatności, co pozwala na uzyskanie informacji o możliwości użycia sp do realizacji lotniczych zadań operacyjnych. Dla wojskowych sp dopuszczalne są trzy stany: zdatny, zdatny z ograniczeniami i niezdatny [22].

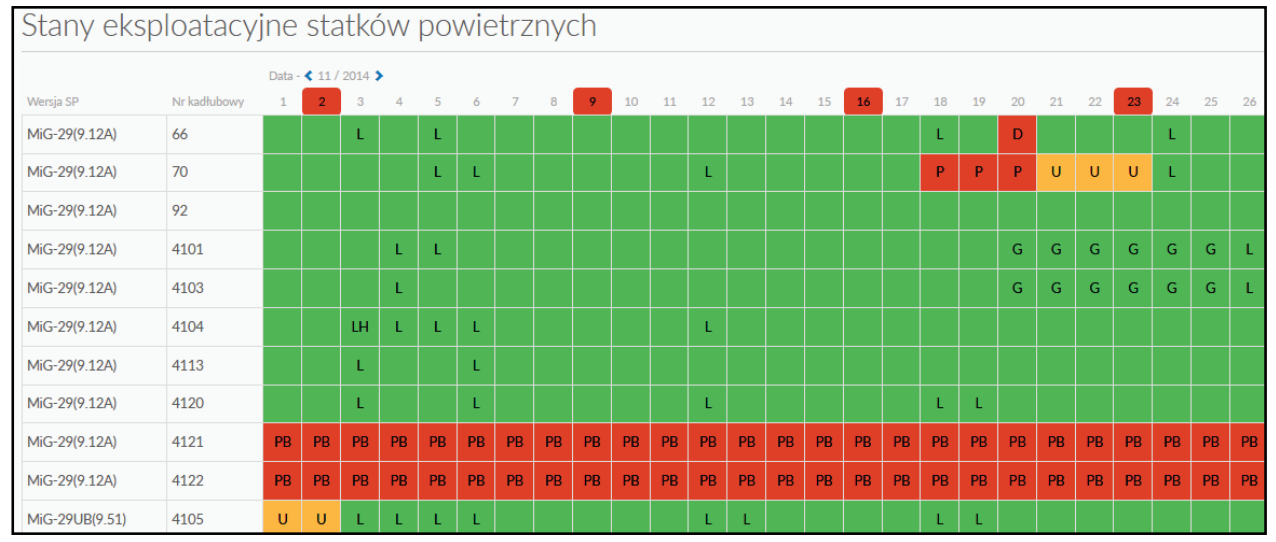

Rys. 7. Przykładowy widok stanów eksploatacyjnych (archiwum ITWL)

Bardzo ważnym zagadnieniem w procesie eksploatacji jest fakt stosowania przez eksploatatorów aktualnej dokumentacji technicznej. SIWEsp w jednym z modułów, który jest w rzeczywistości obszernym katalogiem, zapewnia użytkownikom sp taką możliwość poprzez autoryzowany dostęp do odpowiednich zbiorów. Jest to bardzo ważne, ponieważ wykorzystywanie jedynie zaktualizowanej dokumentacji technicznej jest gwarantem właściwej realizacji wszystkich czynności eksploatacyjnych, a co za tym idzie utrzymaniem odpowiedniej jakości procesu eksploatacji. Istnieją jeszcze inne dokumenty normatywne, do których zalicza się: profilaktyki, biuletyny techniczne, listy serwisowe i dyrektywy zdatności. Wprowadzanie ich w życie umożliwia przeprowadzenie wymaganych modyfikacji lub modernizacji technicznych sprzętu lotniczego, lub elementów systemu eksploatacyjnego (np. zasad eksploatacji sp). Za aktualizację dokumentacji i jej publikację w SIWEsp odpowiada Biblioteka Dokumentacji Technicznej organizacyjnie podlegająca organizatorowi systemu [5,23].

Utrzymywanie statków powietrznych w stanie zdatności technicznej, gwarantujące bezpieczną eksploatację, wymaga przeprowadzenia wielu czynności zgodnie z dokumentacją obsługową. Realizowane jest to w procesie obsługiwania, przez który rozumiemy przedsięwzięcia, mające na celu przeciwdziałanie pojawianiu się niepożądanych zdarzeń, związanych z użytkowaniem statków powietrznych np. pojawianiu się niesprawności sp [25]. Prowadzenie tego procesu ma wpływ nie tylko na niezawodność samolotów i śmigłowców, ale również na ich właściwość, jaką jest żywotność [8,20]. Obsługiwanie jest procesem, który realizowany jest niezależnie od przyjętej strategii eksploatacji statku powietrznego. Jest ono bezpośrednio wspierane przez system logistyczny w zakresie za- 
opatrywania w środki materiałowe niezbędne do realizacji czynności. Obsługiwanie uzależnione jest ponadto od uwarunkowań organizacyjnych i technicznych. W systemie SI SAMANTA proces ten jest wspomagany poprzez następujące funkcje: ewidencję obsług zrealizowanych (planowanych), podgląd ostatnio zrealizowanej obsługi, podgląd historii realizacji wszystkich obsług i prognozowanie kolejnych do realizacji obsług cyklicznych (prezentacja parametrów, przy jakich należy wykonać obsługę). Dla każdego typu statku powietrznego określona jest lista poziomów obsług (katalog), które realizuje się według odpowiednich warunków. Przykładowy cyklogram obsługiwania okresowego przedstawiono na rys. 8 .

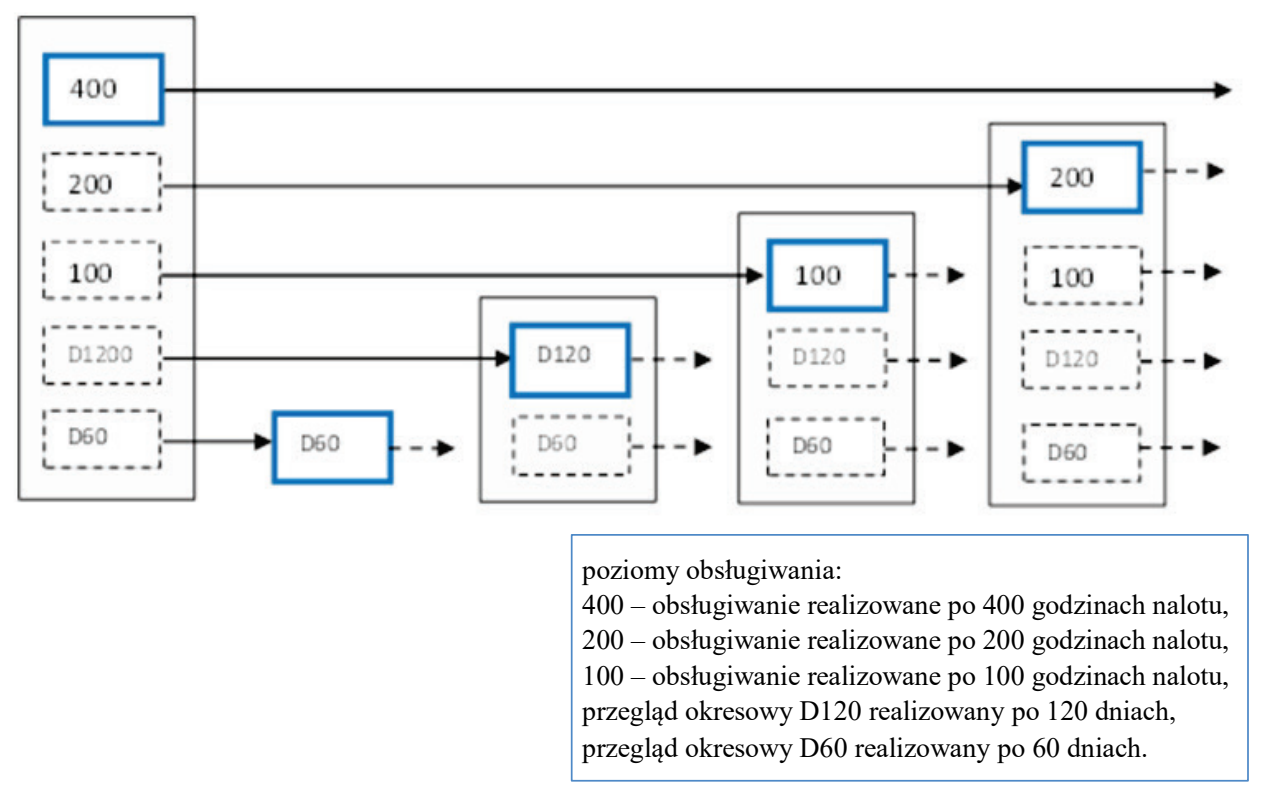

Rys. 8. Cyklogram obsługiwania okresowego dla samolotu Su-22

Kolejny obszar systemu eksploatacji sp dotyczy uszkadzalności statków powietrznych. Informacje o niesprawnościach oraz uszkodzeniach samolotów i śmigłowców, a także ich wyposażenia, gromadzone są w systemie SI SAMANTA w szerokim zakresie. Są to informacje m.in. o miejscu i czasie, objawach, okolicznościach, sposobie naprawy, przyczynach i ewentualnych skutkach. Informacje są bogatym źródłem wiedzy, którą wykorzystuje się w procesie badań eksploatacyjnych.

Równie ważnym obszarem eksploatacji, który wspiera SIWEsp, jest mocno rozwinięta w lotnictwie wojskowym diagnostyka tribologiczna. Na podstawie badań cieczy roboczych zespołów sp, takich jak silniki lotnicze czy przekładnie napędowe, specjaliści laboratoriów oceniają stan techniczny diagnozowanych zespołów. Odpowiednie dokumenty kończące proces analizy tribologicznej trafiają do systemu informatycznego, dając możliwość podejmowania kadrze kierowniczej decyzji o dalszej eksploatacji badanych obiektów. 
Wszystkie obszary i funkcje prowadzone są najczęściej w modułach informatycznych, a ich integracja umożliwia korzystanie ze wspólnych zbiorów danych, co zwiększa efektywność działania systemu informatycznego, a tym samym procesu jego użytkowania. Ułatwia to również wszechstronne raportowanie lub generowanie specjalistycznych zestawień danych oraz informacji. Raporty mogą być przedstawiane w postaci gotowego wzoru lub być tworzone dynamicznie, wówczas to użytkownik decyduje o ostatecznej zawartości i układzie danych w raporcie. Realizowane jest to dzięki właściwościom interfejsu poprzez wybór odpowiednich kryteriów oraz przy użyciu funkcji filtrowania lub sortowania. Przetworzone dane i informacje zestawiane w raportach można zapisywać i eksportować w formie plików PDF lub programu Excell.

Generowane $\mathrm{w}$ ten sposób raporty i zestawienia zawierają szeroki zakres informacji, które wykorzystywane są przez inżynierów lotnictwa do prowadzenia badań eksploatacyjnych. Jednym z głównych obszarów badań jest niezawodność eksploatacyjna samolotów i śmigłowców. Niezawodność (nazywana również nieuszkadzalnością) zależy znacząco od trwałości sp, która niestety z biegiem czasu eksploatacyjnego pogarsza się. W strukturze i elementach sp pomimo wielu przedsięwzięć profilaktycznych pojawiają się niekorzystne zmiany, które w konsekwencji prowadzić mogą do pogorszenia parametrów technicznych. Na niezawodność sp w etapie eksploatacji mają również wpływ uwarunkowania systemu eksploatacji (w tym podsystemu obsługowego), dlatego poziom niezawodności określony przez konstruktora sp, może różnić się od poziomu osiąganego w rzeczywistych warunkach użytkowania. W celu utrzymania właściwego poziomu niezawodności sp w jednostkach lotniczych prowadzi się odpowiednie analizy. Do określenia ważniejszych wskaźników niezawodnościowych posiadających wymiar, należące do grupy tzw. wyznaczników względnych, stosuje się wyrażenia (1) i (2). Równie użytecznym wskaźnikiem niezawodnościowym jest częstość uszkodzeń $[1,13,24]$. Wskaźniki te zawierają informacje o jakości sprzętu lotniczego, a tym samym charakteryzują niezawodność statku powietrznego. Przykładowy wykres parametrów niezawodnościowych przedstawiono na rys. 9.

$$
T_{u}=\frac{T}{N_{u}}
$$

gdzie: $T_{u}$ - średni nalot na jedno uszkodzenie, $T$ - ogólny nalot, $N$ - ogólna ilość uszkodzeń,

$$
T_{u l}=\frac{T}{N_{u l}}
$$

gdzie:

$T_{u l}$ - średni nalot na jedno uszkodzenie w locie, $T$ - ogólny nalot, $N$ - ogólna ilość uszkodzeń w locie. 


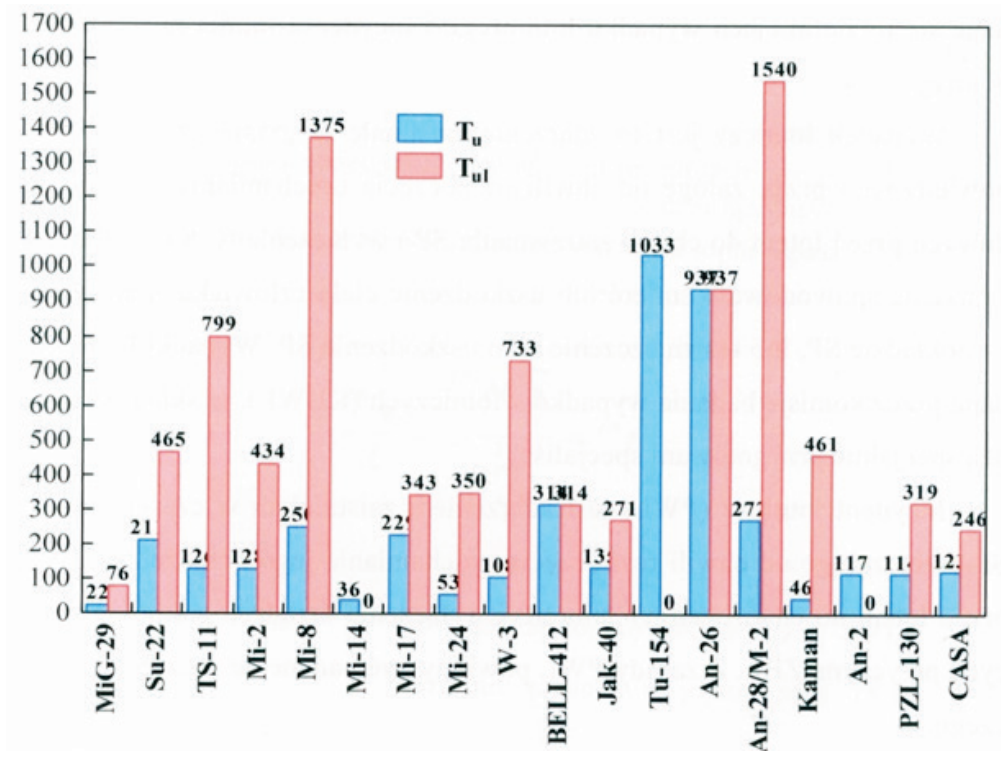

Rys. 9. Przykładowy wykres parametrów niezawodnościowych (archiwum ITWL)

Kolejny obszar poddawany badaniom to proces obsługiwania i napraw. Dane gromadzone w systemie SI SAMANTA, w tym zakresie są źródłem informacji do analiz wskaźnikowych, mogących służyć ocenie efektywności i skuteczności tego procesu. W tym przypadku wykorzystywać można takie wskaźniki bezwzględne jak: czas realizacji obsługiwania, czy ilość niesprawności wykrytych w trakcie realizacji obsługiwania. Wskaźniki skuteczności obsług mogą określać przydatność poszczególnych rodzajów obsług w zakresie wykrywania niesprawności sp, a także ogólnej oceny wydajności systemy obsługowego np. terminowości. W zakresie realizacji napraw sp (po wystąpieniu niesprawności) można stosować wskaźniki charakteryzowane poprzez: czas trwania naprawy (czasochłonność usunięcia niesprawności sp), pracochłonność naprawy, przestój spowodowany brakiem możliwości usprawnienia sp. Wskaźniki naprawialności określają właściwość sp, jaką jest podatność w zakresie jego usprawnienia. Niosą również informacje o skuteczności przeprowadzania procesów w istniejącym podsystemie obsługowym w obszarach, takich jak: infrastruktura techniczna czy kwalifikacje i zaangażowanie techników lotniczych. Można nimi również charakteryzować skuteczność realizacji działań podsystemu logistycznego zaopatrywania w części zapasowe i środki materiałowe $[17,19]$.

$\mathrm{Na}$ rys. $10 \mathrm{w}$ formie graficznej przedstawiono omówione wcześniej obszary, które swoim zasięgiem obejmuje system SI SAMANTA.

Wymienione wyżej obszary badań eksploatacyjnych, prowadzone z wykorzystaniem informacji generowanych z systemu, przekładają się w miarę potrzeb na działania poprawiające np. poziom niezawodności statku powietrznego w celu utrzymania odpowiednich charakterystyk taktyczno-technicznych lub zwiększające efektywność systemu eksploatacji. To z kolei ma bezpośredni wpływ na utrzymanie lub zapewnienie satysfakcjonującego 
poziomu bezpieczeństwa lotów. Obszar bezpieczeństwa lotów i wszystkich przedsięwzięć profilaktycznych z nim związanych jest bardzo ważny, a jak głosi jeden z aksjomatów: zdarzenia lotnicze (incydenty i wypadki) oraz związane z nimi straty są nie do uniknięcia, co najwyżej można zmniejszyć ich wielkość i częstotliwość występowania [10]. Mają one najczęściej charakter losowy $[2,11]$ z tego powodu personel SIL dokłada wszelkich starań, aby dane dostępne w SIWEsp wykorzystywać do analiz w sposób ciągły i skutecznie przeciwdziałać zagrożeniom, wpływającym na bezpieczeństwo lotów szczególnie zagrożeniom natury technicznej.

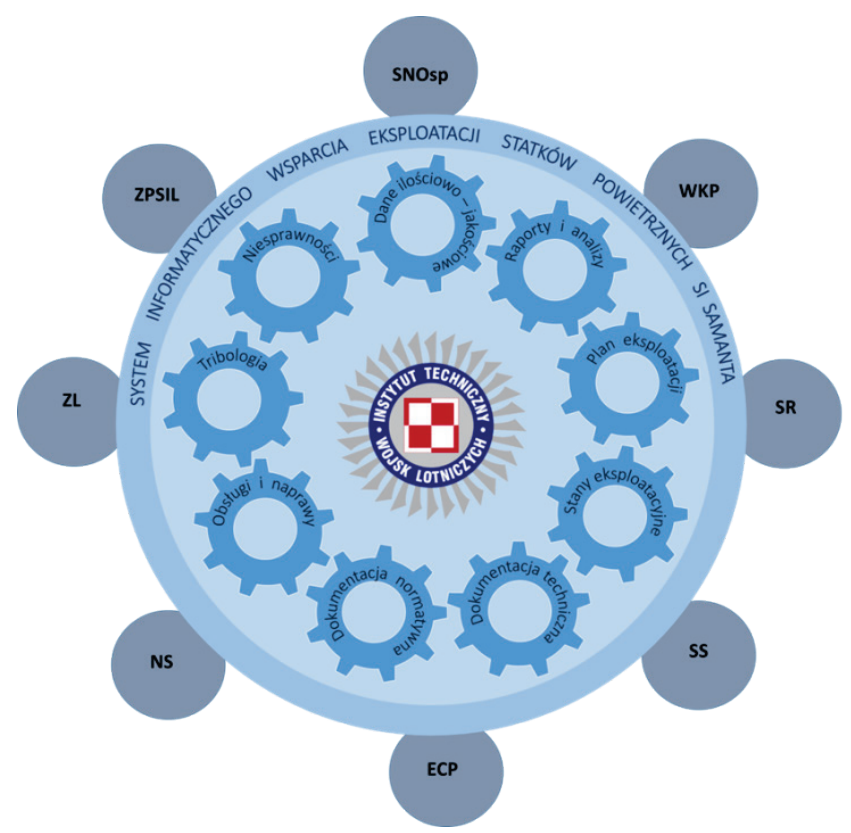

Rys. 10. Obszary funkcjonalne systemu SI SAMANTA

Jak widać SI SAMANTA stanowi kompleksowy system wspomagania procesu eksploatacji techniki lotniczej. Oznacza to, że poza bezpośrednim wsparciem zarządzania flotą statków powietrznych (wewnętrzne moduły koła), wspomaga również obszary, bez których użytkowanie samolotów i śmigłowców byłoby niemożliwe. Do najważniejszych obszarów uzupełniających eksploatację sp, widocznych na rys.10 jako zewnętrzne moduły koła, należą:

- SNOsp - sprzęt naziemnej obsługi statków powietrznych (np. dystrybutory tlenu, azotu, zasilacze elektroenergetyczne i hydrauliczne),

- WKP-wyposażenie kontrolno-pomiarowe,

- SR - sprzęt ratowniczy,

- SS - sprzęt spadochronowy,

- ECP - ewidencja czasu pracy, 
- NS - narzędzia specjalistyczne,

- ZL - zabezpieczenie logistyczne.

W odniesieniu do wymienionych zasobów, funkcjonalności systemu SI SAMANTA pozwalają one prowadzić czynności w zakresie: ewidencji, identyfikacji, określania stanu ilościowego, określania stanu sprawności, planowania uwierzytelnień aparatury itp. Poza wymienionymi wyżej obszarami istnieje jeszcze moduł ZPSIL, pozwalający na zarządzanie zasobami personelu SIL przez: ewidencję specjalistów, ewidencję ich kwalifikacji (świadectw, uprawnień, upoważnień, znajomości języków obcych itd.), planowanie szkoleń lub kursów oraz monitorowanie ważności nabytych uprawnień.

\section{Kierunki rozwoju systemów informatycznego wspierających eksploatację sp}

Szeroki zakres zalet, jakimi charakteryzują się systemy informatycznego wspomagania, powodują, że ich stosowanie przy realizacji różnych procesów jest uzasadnione. Jednak w przypadku potrzeby udoskonalania rzeczywistego systemu eksploatacji sp, o czym wspomniano wcześniej, wprowadza to konieczność ciągłej aktualizacji lub zwiększania użyteczności funkcjonalnej istniejącego już systemu. Wymusza to na projektodawcach SI SAMANTA realizacji adekwatnych działań w celu zabezpieczenia ciągłego wspomagania przez SIWEsp. Obecnie prowadzone w ITWL prace koncepcyjne, mające na celu rozszerzenia użyteczności SI SAMANTA, skupiają się na:

- zabezpieczeniu wsparcia zarządzania procesem ciągłej zdatności do lotu sp w świetle planowanych do wprowadzenia nowych wymagań European Military Airworthiness Requirements EMAR (pol. Europejskie Wojskowe Wymagania Zdatności do Lotu),

- opracowaniu modelu modułu zarządzania jakością procesów produkcji, napraw i dostaw sprzętu techniki lotniczej,

- opracowaniu uniwersalnego modelu wsparcia zarządzania procesem obsługiwania na poziomie realizacji czynności z możliwością ewidencji parametrów kontrolowanych.

Od prawie sześciu lat trwają prace, zmierzające do ujednolicenia w Unii Europejskiej przepisów, dotyczących wymagań zdatności do lotu wojskowych statków powietrznych. Sprawami tymi zajmuje się Forum Wojskowych Nadzorów Zdatności do Lotu MAWA (MilitaryAirworthines Autority Forum). Od 2013 r., kiedy to Polska podpisała Podstawowy Dokument Ramowy (BFD) obligujący wojskowe organy zdatności do lotu państwa europejskie, deklarując przyjęcie zharmonizowanych Europejskich Wymagań Zdatności do Lotu Wojskowych Statków Powietrznych, przedstawiciele ITWL biorą czynny udział w pracach MAWA Forum. Przepisy EMAR mają na celu ujednolicenie wymagań (standardów) dotyczących zdatności do lotu, procesu certyfikacji oraz regulacji ich wzajemnego uznawania. Obejmują przedsięwzięcia związane z funkcjonowaniem organizacji lotniczych 
oraz wymagań sprzętu lotniczego. Pełna implementacja do narodowych przepisów zdatności do lotu wojskowych statków powietrznych w postaci polskich wymagań EMAR spowoduje najprawdopodobniej potrzebę rozszerzenie funkcjonalności systemu SI SAMANTA w zakresie:

- wprowadzenia udogodnień systemowych w celu sprawnego zarządzania wszystkimi wymaganiami mającymi wpływ na ciągłą zdatność do lotu np. poprzez wprowadzenie i wykorzystywanie informatycznych statusów (np. w module zakładkowym) podających informacje o:

-ważności resursów technicznych i międzynaprawczych - zapasie resursu płatowca, zespołów i elementów o ograniczonej żywotności,

- kompletnej zabudowie zgodnej z listą wyposażeniu samolotu,

- realizacji programów obsług technicznych,

- ważności resursów międzyobsługowych,

- realizacji obowiązujących profilaktyk,

- realizacji obowiązujących biuletynów,

- realizacji obowiązujących listów serwisowych,

- realizacji obowiązujących dyrektyw zdatności,

- aktualności dokumentacji technicznej,

- ważności certyfikatów, świadectw, poświadczeń,

- realizacji cyklicznej kontroli jakości danych i informacji w SI,

- specjalistycznych analiz niesprawności sp i analiz wskaźników eksploatacyjnych,

- możliwości zarządzania nowymi dokumentami (certyfikaty, poświadczenia świadectwa) w zakresie: archiwizowania i prognozowania potrzeby ich odnowienia lub aktualizacji.

W drugim obszarze prace analityczne w zakresie opracowania modelu zarządzania jakością procesu produkcji, przekazywania sprzętu techniki lotniczej do użytkowników i kontroli procesu naprawy mają na celu udostępnienie nowych funkcjonalności przedstawicielom GQA (procesu rządowego zapewnienia jakości), którzy ustawowo wyznaczeni są do monitorowania tego obszaru. Działają oni na podstawie przepisów określanych cywilną normą ISO 9001:2015 oraz wojskową normą AQAP 2110, stosowanych w podmiotach Gospodarki Narodowej realizujących usługi na potrzeby Sił Zbrojnych. Wymienione normy nie są komplementarne, dlatego należy pamiętać o istnieniu innych np. AQAP 2210 czy AQAP 2310. Jednym z zasadniczych elementów realizacji kontroli procesu jakości z wykorzystaniem SIWEsp będzie planowana do wdrożenia cyfryzacja książki reklamacji. Gromadzenie danych o pojawiających się reklamacjach oraz przebiegu ich realizacji, dzięki analizie zebranych informacji, może skutkować w dalszej analizie wartościowymi wnioskami (np. co i jak często jest reklamowane, przez kogo jest naprawiane itp.).

Wprowadzenie informatycznego wsparcia prowadzonego przez system SI SAMANTA do zarządzania procesem obsługiwania w Eskadrze Technicznej (ET) jednostki lotniczej może zostać wykorzystane do kierowania i sterowania realizacją czynności obsługowych. Czynności te realizowane obecnie są z wykorzystaniem papierowych wersji kart technologicznych, tworzących harmonogram realizacji czynności obsługowych w ET. 
Wprowadzenie wspomagania informatycznego prowadzenia harmonogramów cyklu obsługowego z wykorzystaniem cyfrowych kart technologicznych może ułatwić:

- ewidencję poszczególnych czynności z możliwością kontroli ich kompletności i śledzenia postępu wykonania,

- ewidencję czasu realizacji poszczególnych czynności, identyfikację osoby wykonującej i kontrolującej,

- archiwizację kontrolowanych parametrów technicznych.

\section{Wnioski}

1. Informatyczne wsparcie $\mathrm{z}$ uwagi na swoje zalety odgrywa istotną rolę w zarządzaniu realizacją procesów w Systemie Logistycznym SZ RP. Przykładem jest system SI SAMANTA stosowany w procesie eksploatacji wojskowych statków powietrznych.

2. Zaprojektowany oraz opracowany przez ITWL system SI SAMANTA stanowi kompleksowe unikatowe narzędzie informatyczne wspomagania eksploatacji statków powietrznych zwiększające efektywność oraz skuteczność realizacji zadań użytkowników systemu podczas realizacji skomplikowanego procesu użytkowania sp.

3. Elastyczność systemu w zakresie jego modyfikacji (polska myśl informatyczna) umożliwia szybkie dostosowywanie funkcjonalne według potrzeb użytkownika lub według aktualizacji wynikających ze zmian formalnych dokumentacji eksploatacyjnej.

4. SI SAMANTA charakteryzuje się dużym potencjałem w zakresie rozszerzenie zakresu użyteczności w planowanych do opracowania i wdrożenia obszarach, nad którymi obecnie pracują specjaliści z ITWL.

5. Wdrożenie wsparcia w zakresie nowych obszarów i funkcji systemu SI SAMANTA może znacząco przyczynić się do bezpieczeństwa lotów wojskowych statków powietrznych.

\section{Literatura}

1. Będkowski L., Dąbrowski T.: Podstawy eksploatacji, cz. II, Podstawy niezawodności eksploatacyjnej. WAT, Warszawa 2006.

2. Borgoń J. i inni: Niezawodność statków powietrznych. ITWL, Warszawa 1992.

3. Chmielarz W.: Systemy informatyczne wspomagające zarządzanie. DW ELIPSA, Warszawa 1996.

4. Instrukcja o gospodarowaniu mieniem techniki lotniczej. DU-4.22.6, Warszawa 2017.

5. Instrukcja opracowywania i realizacji biuletynów technicznych w Lotnictwie Sił Zbrojnych RP. DU-4.22.6.02, Bydgoszcz 2016.

6. Instrukcja służby inżynieryjno-lotniczej lotnictwa SZ RP (ISIL-2017), Bydgoszcz 2017. 
7. Instrukcja zarządzania ruchem lotniczym w Siłach Zbrojnych RP, Warszawa 2017.

8. Janusiak K.: Żywotność statku powietrznego. Przegląd Logistyczny, nr 2 (010), 2010.

9. Jaźwiński J., Żurek J.: Wybrane problemy sterowania zapasami. WITE-PIB, Radom 2007.

10. Karpowicz J., Klich E.: Zarządzanie bezpieczeństwem w lotnictwie. WSOSP, Dęblin 2011.

11. Krystek R.: Zintegrowany system bezpieczeństwa transportu, T.1. WKŁ, Gdańsk 2009.

12. Kurasiński Z. i inni: Kompendium logistyka wojskowego. SG WP, Warszawa 2014.

13. Lewitowicz J., Żyluk A.: Podstawy eksploatacji statków powietrznych, T. 5. Techniczna eksploatacja statków powietrznych. ITWL, Warszawa 2009.

14. Lewitowicz J.: Eksploatacyjne własności i właściwości samolotów i śmigłowców. ITWL, Warszawa 2015.

15. Lewitowicz J.: Podstawy eksploatacji statków powietrznych, T. 6. Eksploatacyjne problemy w projektowaniu i modernizacji statków powietrznych. ITWL, Warszawa 2012.

16. Lewitowicz J.: Podstawy eksploatacji statków powietrznych, T.3. Systemy eksploatacji statków powietrznych. ITWL, Warszawa 2006.

17. Mitkow Sz.: Logistyka w procesie modernizacji technicznej. Przegląd Logistyczny, nr 2 (060), 2009.

18. Pawlisiak M.: Funkcjonowanie systemu logistycznego Sił Zbrojnych RP a bezpieczeństwo narodowe, część 2. Systemy Logistyczne Wojsk, nr 41/2014.

19. Tomaszek H., Wróblewski M.: Podstawy oceny efektywności eksploatacji systemów uzbrojenia lotniczego. BELLONA, Warszawa 2001.

20. Ważny M., Stepień S., Zieja M.: Outline of a method for estimating the durability of components or device assemblies while maintaining the required reliability level. Eksploatacja i Niezawodnosc, Volume 20, Issue 2, 2018.

21. Wsparcie i zabezpieczenie techniczne Sił Zbrojnych Rzeczypospolitej Polskiej. Zasady funkcjonowania. DD-4.22, Warszawa 2017.

22. Zasady oceny stanu technicznego uzbrojenia i sprzętu wojskowego w SZ RP. DD/4.22.12, Bydgoszcz 2013.

23. Zieja M., Smoliński H., Gołda P.: Information systems as a tool for supporting the management of aircraft flight safety. Archives of Transport, Volume 36, Issue 4, 2015.

24. Zieja M., Tomaszewska J., Woch M.: Analysis of the time between failures of aircrafts, 2nd International Conference on System Reliability and Safety, ICSRS 2017, Volume 2018, 29 January 2018.

25. Żak J., Kowalski M.: System obsługi technicznej statków powietrznych w WSOP. Prace Naukowe Politechniki Warszawskiej, z.118/2017. 